\title{
CONGENITAL PYLORIC STENOSIS IN OLDER BABIES
}

\author{
BY \\ JOHN RENDLE-SHORT and R. B. ZACHARY \\ From the Department of Child Health, the University of Sheffield, and the Children's Hospital Unit, \\ the United Sheffield Hospitals
}

(RECEIVED FOR PUBLICATION JULY 19, 1954)

The usual age of onset of symptoms in congenital hypertrophic pyloric stenosis is between the second and sixth week of life. Occasionally vomiting does not become severe enough to raise the question of the diagnosis of pyloric stenosis until the eighth week, but in such cases there is frequently a history of less severe vomiting during the previous two or three weeks. Table 1 gives details from published reports

TABLE 1

MAXIMUM AGE AT ONSET OF SYMPTOMS OR ADMISSION TO HOSPITAL IN SIX SERIES OF CASES OF PYLORIC STENOSIS

\begin{tabular}{|c|c|c|c|}
\hline & $\begin{array}{l}\text { No. of } \\
\text { Cases }\end{array}$ & $\begin{array}{c}\text { Maximum } \\
\text { Recorded } \\
\text { Age at } \\
\text { Onset }\end{array}$ & $\begin{array}{l}\text { Maximum } \\
\text { Age at } \\
\text { Admission } \\
\text { to Hospital }\end{array}$ \\
\hline $\begin{array}{c}\text { Lanman and Mahoney } \\
(1933)\end{array}$ & 425 & - & 20 weeks \\
\hline $\begin{array}{c}\text { Thompson and Gaisford } \\
(1935)\end{array}$ & 209 & 6 weeks & - \\
\hline McLaren Todd (1947) & 112 & 8 weeks & - \\
\hline $\begin{array}{c}\text { Grimes, Bell and Olney } \\
(1950)\end{array}$ & 119 & - & 5 months \\
\hline $\begin{array}{l}\text { Ward-McQuaid and Porritt } \\
\qquad(1950) \quad \ldots\end{array}$ & 100 & 8 weeks & - \\
\hline Wood and Smellie (1951) ... & 320 & 3 months & - \\
\hline
\end{tabular}

which recorded the maximum age at which symptoms developed.

In a study of the literature only one account of the condition has been found in a child over the age of 3 months, and in that case there is great doubt regarding the diagnosis. The child (Paisseau, Boegner, Brouet and Vaille, 1935) was perfectly well until 22 months of age, when he was admitted to hospital with a history of vomiting for eight days. He was grossly dehydrated but there were no other symptoms. A barium meal showed no evacuation of the stomach contents by the end of 22 hours. A provisional diagnosis of pyloric stenosis was made and antispasmodics given, but as the vomiting continued laparotomy was undertaken. No pyloric tumour was palpable at operation but an extramucous pyloromyotomy was performed. The childo still did not improve and another radiograph of thei abdomen revealed that barium was retained from the barium meal given six days before. Gastro- $\frac{\vec{b}}{0}$ enterostomy was then performed and the child immediately ceased vomiting. It is noteworthy that the surgeon did not consider pyloric stenosis to be the precise diagnosis as he was not able to find a pyloric tumour.

\section{Case Reports}

Case 1. This first-born boy was said by his parents to have been perfectly well until 10 days before admissign $\overrightarrow{0}$ to hospital. He was just under $5 \frac{1}{2}$ months of age agdo weighed $13 \mathrm{lb}$. The mother gave the history that 10 days the child had vomited every feed, the vomitiong being sudden and violent, and occurring immediat after the feed or within 10 minutes of it. The vomitus consisted of food or watery material with 'phlegm' in it, but no bile. In addition the baby brought up a great dealī of wind and was constipated. Some discharge from the $\stackrel{\varrho}{\rightarrow}$ ears had been noticed and also a little bloodstained nasalo을 discharge. On examination the baby was listless and ill, and although there was evidence of considerable loss of weight and dehydration, this appeared recent, the impression being of a healthy, normally developed childo who had suddenly been struck down by some acute illness. The right ear drum was injected but no perfora-otion was seen. The abdomen was lax, and a tumour? was palpable in the epigastrium, but the diagnosis of pyloric stenosis was at first discounted owing to the 3 baby's age.

The urine contained $220 \mathrm{mg}$. \% of albumin, uro-을 bilinogen in excess of normal, and a large number of cellular and granular casts.

The carbon dioxide-combining power was 90 vols. $\%$ (40 mEq./litre), the chloride (as $\mathrm{NaCl}$ ) level $310 \mathrm{mg} . \%$ (53 mEq./litre), sodium $304 \mathrm{mg} . \%$ (132 mEq./litre), and 0 potassium $9.4 \mathrm{mg}$. \% (2.4 mEq./litre). A white cell count gave 4,600 per c.mm. of which $74 \%$ were polymorphs.

The child was given intravenous fluids, but his condition deteriorated and he started to vomit altered blood. As it was thought that he might have a hiatus hernia with oesophagitis or even a duodenal ulcer, a barium swallow- 
was performed. This showed complete retention of the barium at three and a half hours, and even at 17 hours some barium remained in the stomach. It thus became clear that the mass felt must in fact be a pyloric tumour, and at operation a tumour was found which was large and thick but not hard. The muscle was split, with excellent results. The child stopped vomiting and gained $1 \frac{1}{2} \mathrm{lb}$. in nine days.

Case 2. This child, the second of two boys, the other of whom was normal, weighed $6 \frac{1}{2} \mathrm{lb}$. at birth and was perfectly well until 3 months of age by which time he weighed $11 \frac{1}{2} \mathrm{lb}$. He then began to have projectile vomits, and at another hospital was found to have a pyloric tumour. Visible peristalsis was present. He was treated with methyl atropine nitrate $(1$ in 10,000$)$, but as his vomiting did not cease he was transferred to the Sheffield Children's Hospital. An operation was performed and revealed a pyloric tumour 1 in. in length, nearly $\frac{3}{4}$ in. in width and $\frac{1}{4}$ in. in thickness, which did not feel hard. The child made a good recovery.

\section{Discussion}

These two cases and the one reported by Paisseau et al. are recorded because they show that, despite its undoubted rarity, congenital pyloric stenosis may occur in babies over the normally accepted age, and therefore the diagnosis should not be discounted solely on this score.

Another reason for recording these cases is because they demonstrate that many weeks may elapse before the onset of symptoms.

It is not clear why children predisposed to pyloric stenosis should begin to vomit at any particular time but there are probably two factors involved: hypertrophy of the pyloric muscle decreases the lumen of the canal, and at the same time, the calibre of the gut, including the pylorus, increases as the child grows. The critical phase comes when the muscle of the pylorus has hypertrophied but its lumen is still quite small. Obstruction can then readily take place, especially if oedema of the gastric mucosa develops either as the result of infection or from mechanical irritation. In older babies, in whom the lumen of the pyloric canal is larger, as is indicated by the flabbiness of the tumour palpated at operation, perhaps greater mucosal swelling is required before symptoms develop. This may account for the rareness of the condition in older infants. It is of interest that Case 1 had otitis media on admission and an upper respiratory infection may have precipitated the onset of vomiting.

\section{Summary}

Two children are described in whom symptoms of pyloric stenosis did not occur until $5 \frac{1}{2}$ and 3 months of age respectively. A third doubtful case in which symptoms were delayed until 22 months has been described in the literature.

The cause of the latent period before the onset of symptoms is discussed.

Our thanks are due to Professor R. S. Illingworth for permission to publish and for helpful criticism.

REFERENCES

Grimes, O. F., Bell, H. G. and Olney, M. B. (1950). J. Pediat,, $37,522$.

Lanman, T. H. and Mahoney, P. J. (1933). Surg. Gynec. Obstet., $56,205$.

Paisseau, Boegner, Brouet and Vaille (1935). Bull. Soc. Pédiat, Paris, 33, 361.

Thompson, W. A. and Gaisford, W. F. (1935). Brit. med. J., 2, 1037. Todd, R. McLaren (1947). Archives of Disease in Childhood, 22, 75. Ward-McQuaid, J. N. and Porritt, B. E. (1950). Lancet, 1, 201.

Wood, E. C. and Smellie, J. M. (1951). Ibid., $2,3$. 